\title{
Clinical Application of Renograph IR-03 for the Hospital
}

\author{
R. Isaris ${ }^{*}$, J. Sumanto ${ }^{2}$, Suharni ${ }^{1}$, P. Bagaswoto ${ }^{3}$ and E. Purwanti ${ }^{3}$ \\ ${ }^{1}$ Center for Technology of Accelerator and Material Process, National Nuclear Energy Agency \\ Jl. Babarsari POBox 6101 ykbb, Yogyakarta 5528, Indonesia \\ ${ }^{2}$ Center for Nuclear Instrumentation Engineering, National Nuclear Energy Agency \\ Puspiptek, Serpong-Tangerang 15310, Indonesia \\ ${ }^{3}$ Dr. Sardjito General Hospital Jogyakarta \\ Jl. Kesehatan No.1 , phone (0274) 587715 Yogyakarta, Indonesia
}

\section{ARTICLE INFO}

Article history:

Received 28 April 2011

Received in Revised form 03 July 2012

Accepted 07 July 2012

Keywords:

Cost analyses

Renography diagnostic

Utilization of radioisotope

\begin{abstract}
A B S T R A C T
The renography using renograph is one of clinical modality to investigate the renal function among other such as laboratory medical check up and X-rays. The prototype of renograph IR-03 designed by BATAN has been constructed and the laboratory tests as well as clinical tests have been carried out at PRPN-BATAN Serpong and General Hospital Dr. Sardjito Jogyakarta, respectively. Cost associated with the clinical use of renograph at the hospital are analyzed according to the two major components: radiopharmaceutical cost and the use of equipment. Annual cost of operational of renograph by estimate number of patient is about 2,000 is IDR. 30.0 millions for radiopharmaceutical ${ }^{131}$ Iodine. Total Direct Cost is about IDR. 212.5 millions and the Capital Cost for one unit renograph is IDR. 250 millions. The Break Event Point of invest one unit renograph is 1194 procedures $(0.597 \%)$, or about IDR. 209,475 millions, which the cost for each procedure is IDR. 85,000.-. This value is depending on several variables, especially number of procedure can be reached. The cash flow analyses by Rate of Return (ROR) showed that the value of $i^{*}$ is $22.6 \%$ is much greater than the value of MARR or saving rate of interest in the Bank now is about $<10 \%$. The Payback Period calculation to see on how interesting the investment of renograph and its prospect for application in the hospitals showed about 1.818 years, that is good prospect economically.
\end{abstract}

(C) 2012 Atom Indonesia. All rights reserved

\section{INTRODUCTION}

Recently, the difference of renal function shows the increasing in number, about $12.5 \%$ (25 million) populations were suffered of malfunction of kidneys, and 20,000 new patients per 1 million population in a year was recorded in government hospitals [1]. The medical service for renal function test in hospitals is obstacle by lack of number of equipment available in hospitals that must be imported and not produced anymore by developed countries as well as costly.

Since 1985 BATAN has developed numerous of renograph's prototypes. Innovation technology was made in order to match the design to the new technology (state of the art), to increase the quality and performances of equipment, to make simplicity and smoothing to users in hospital. renograph IR-03 is an instrument for examination of kidneys function based on radioisotope technology, it is

\footnotetext{
* Corresponding author.

E-mail address: risaris2001@yahoo.com
}

compact and able to identify specifically the status of each kidney and shows the calculation of kidney function parameters and shows it in monitor. renography techniques is a modality of kidney function examination that more specific than the conventional ones such as laboratory examination (check-up of creatinine, ureum and urid acid parts in blood), or X-Rays modality, and it has a potential diagnostic values that is specific and measurable for each kidney personally. Quantification of kidney function with radionuclides is an accurate and perfect methods for total evaluation and differential (split, relative) of kidney function based on Smith concept [2].

Monitoring externally on the area where the kidneys are, will produce radioisotope activity curve versus time that shows the change of radioisotope activity in the body (organ) to the time of counting. The uptake phase to the radiopharmaceutical becomes the basis for the value of Glomerolous Filtration Rate (GRF) and Effective Renal Plasma Flow (ERPF) of each kidney. Study on the evolution and development technology of those renographs in 
case of component sophistication and state of the art technology, interface and computer system, as well as Process Regulation and Control System, showed the real progress in system reliability and display [3].

One set of the equipment has been successfully constructed in the year 2009 founded by Office of Ministry of Research and Technology under an Incentive Research Program, Contract Number: $\quad$ 025/KP/D.PSIPTN/Insentif/PPK/2009. Under this program, BATAN has developed a new generation of renograph, namely renograph IR-03. This design has considered the state of the art components used, patient ergonomy, the system integrity for easier mobility to the rural areas, and data processing using new computer generation. The Basic Engineering Design Package (BEDP) of System and Technical Documents required have been finished during the year 2007, then followed by constructing a prototype of renograph IR-03 as a Demo Plant Equipment for clinical test and preparation documents for getting the production certificate. The clinical test was carried out in Dr. Sadjito General Hospital Jogyakarta. The tests were aimed to observe the technology design that can be showed through the successful of instrument operation, the rate of instrument's malfunction, the user satisfaction, the successful in performing the diagnosis for patients. Moreover, the objective of this clinical test is to obtain the operational data of instrument for Techno-economy feasibility study, cost analysis and promotion for investment consideration of renograph in the hospital.

In principle, almost all the renograph equipment design is based on common nuclear spectroscopy system using scintillation or solid state detector, and the system development can be made on the data processing and display [4], for example by using microcontroller or computer system.

\section{EXPERIMENTAL METHODS}

\section{Technology review}

Renal organ is composed by tissues called tubulous system that controls and separates body liquid produced by metabolism in the human body, and then excretes the un-use components through urine. Each kidney has around 1.2 millions neuphron that doing the filtering process, re-absorption, and separation them. According to its function, neuphron is divided into two parts, that is glomeroleus as a filter and tubulous that processing the filtered product and re-absorps process, then separate the rest and excretes it together with urine.
Looking at the mechanism of urine production, renal functions are used for the following purposes [3]:

- To regulate the balance of body liquid volume and its composition, it covers the regulation of the volume of blood and the ionic concentration of $\mathrm{K}, \mathrm{Na}, \mathrm{Mg}$, Ca elements, etc.

- To regulate the balance of acid-base, which consist of the concentration regulation of hydrogen ion in body extra celular liquid. Failure of kidneys in this function, causes the patient be coma in case of liquid was ultra-acid, and causes the patient be oedem in case of the liquid was ultra-base.

- To regulate the body blood pressure in the long run. Failure in this function indicates the damage of neuphron that showed by the change of glomerolous filtration coefficient. The regulation of body pressure in the short and medium ranges was done by nerves and hormone as well as vascular stress relaxation, respectively.

Diagnose to the kidney is based to the analysis to the renal-function curve, that is to detect the radioactivity distribution come from a man/woman organ that injected by radiopharmaceutical liquid through intra-vena, such as ${ }^{131}$ Iodine (energy $364 \mathrm{keV}$, and $\mathrm{T}_{1 / 2}=8$ days) or ${ }^{99 \mathrm{~m}}$ Tc DTPA $(140 \mathrm{keV})$ that emits gamma rays. Number of radioactivity which go into, precipitates in and go out from kidney give a specific distribution against time, that called uro-dynamic curve of renal function or renogram, that can be divided into three region [5], and can be identified into five patrons [6], as shown in Fig. 1.

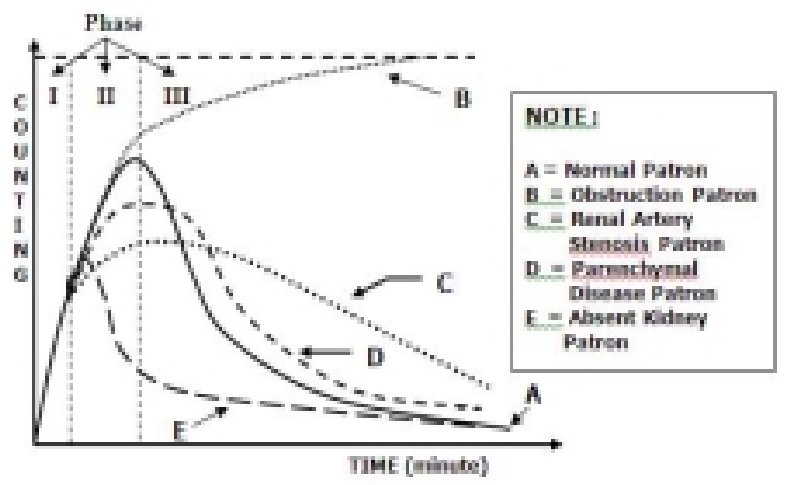

Fig. 1. Phases and Patrons of Renogram Curve.

- Phase I ( vascular phase): indicates the capacity and integrity of renal blood artery

- Phase II (parenchyma phase) : indicates the absorption capacity of kidneys

- Phase III (excretion phase) : indicates the capacity of kidneys for excretion process. 
While the five patrons possibility of renogram curve are : $\mathrm{A}=$ normal patron, $\mathrm{B}=$ obstruction patron, $\mathrm{C}=$ renal artery stenosis patron, $\mathrm{D}=$ parenchyma diseases patron and $\mathrm{E}=$ absent kidney patron.

In order to make accurate interpretation for diagnosis to the observed renogram curve, 11 kidney parameters showed in Table 1 were introduced [7]. The renogram curve and those eleven calculated parameters were displayed in monitor and can be scanned by a printer, and use it as a patient document.

Table 1. Eleven kidney parameters formulas for renogram curve diagnosis

\begin{tabular}{|c|c|c|}
\hline No. Notation & Definition & Formula/Description \\
\hline 1. $\mathrm{T}_{\max }$ & $\begin{array}{l}\text { Time needed to reach } \\
\text { the maximum } \\
\text { counting } \mathrm{C}_{\max }\end{array}$ & $\begin{array}{l}\text { to reach the peak of renogram } \\
\text { curve }\end{array}$ \\
\hline 2. $\mathrm{C}_{\max }$ & Counting maximum & Counting rate at the peak of curve \\
\hline 3. $\mathrm{T}_{1 / 2}$ & $\begin{array}{l}\text { Time interval between } \\
T_{\max } \text { and time when } \\
\text { counting equal to } \\
1 / 2 \mathrm{C}_{\max }\end{array}$ & $\begin{array}{l}\text { To observe the rate of excretion } \\
\text { by kidney up to a half of } \\
\text { radioisotope activity. }\end{array}$ \\
\hline 4. $\mathrm{T}_{2 / 3}$ & $\begin{array}{l}\text { Time interval between } \\
\mathrm{T}_{\max } \text { and time when } \\
\text { counting equal to } \\
2 / 3 \mathrm{C}_{\max }\end{array}$ & $\begin{array}{l}\text { To observe the rate of excretion } \\
\text { by kidney up to } 2 / 3 \text { of } \\
\text { radioisotope activity. }\end{array}$ \\
\hline 5. $\mathrm{C}_{\mathrm{T} 10}$ & $\begin{array}{l}\text { Counting number at } \\
\text { time } t=10 \text { menit }\end{array}$ & For Excretion capacity calculation \\
\hline 6. Up-Slope & $\begin{array}{l}\text { Gradient at phase } \mathrm{II} \\
\text { (raise), } \\
\mathrm{C}_{\mathrm{T} 1}=\text { counting at } \mathrm{t}=\mathrm{T}_{1} \\
(\text { end of phase } \mathrm{I} \text { ) }\end{array}$ & $U S=\frac{C_{\max }-C_{T 1}}{C_{\max }} x \frac{1}{T_{\max }-T_{1}}$ \\
\hline $\begin{array}{l}\text { 7. } \mathrm{DS} \mathrm{T}_{1 / 2} \\
\mathrm{CT}_{1 / 2}\end{array}$ & $\begin{array}{l}\text { Gradient curve } \\
\text { between point at } \\
t=T_{\max } \text { and point at } \\
t=T_{2 / 3} \\
\text { Counting in this } \\
\text { condition }=1 / 2 C_{\max }\end{array}$ & $D S T_{1 / 2}=\frac{C_{\max }-C T_{1 / 2}}{C_{\max }} \times \frac{1}{T_{1 / 2}}$ \\
\hline $\begin{array}{l}\text { 8. Down- } \\
\text { Slope } \\
\text { DS T }_{2 / 3} \\
\mathrm{CT}_{2 / 3}\end{array}$ & $\begin{array}{l}\text { Gradient curve } \\
\text { between point } t=T_{\max } \\
\text { and point at } t=T_{1 / 2} \\
\text { Counting in this } \\
\text { condition }=2 / 3 C_{\max }\end{array}$ & $D S T_{2 / 3}=\frac{C_{\max }-C_{T 2 / 3}}{C_{\max }} \times \frac{1}{T_{2 / 3}}$ \\
\hline $\begin{array}{l}\text { 9. Reno } \\
\text { Index } \\
\left(\mathrm{T}_{(80-140)}\right.\end{array}$ & $\begin{array}{l}\text { The comparison } \\
\text { between the integral } \\
\text { curve of the second } \\
\text { phase of renogram } \\
\text { curve at the time } \\
\text { interval } t=80 \text { second } \\
\text { to } 140 \text { second } \\
\text { ( for the two kidneys) }\end{array}$ & $R I=\frac{\int_{80}^{140} C_{\text {Left }}(t) d t}{\int_{80}^{140} C_{\text {Right }}(t) d t}$ \\
\hline $\begin{array}{l}\text { 10. } \text { RUD }_{\text {Right }} \\
\text { (in \%) }\end{array}$ & $\begin{array}{l}\text { The estimation of each } \\
\text { kidney capacity to up- } \\
\text { take radioactive tracer } \\
\text { injected. } \\
\text { (The same formula for } \\
\text { Left kidney) }\end{array}$ & $R U D_{\text {ight }}=\frac{C_{\max (R)}-C_{T 1}}{\left[C_{\max (R)}-C_{T(R)}\right]\left[C_{\max L e f t}-C_{T(L)}\right]} x 10 \%$ \\
\hline $\begin{array}{l}\text { 11. Individual } \\
\text { Excretion } \\
\text { (\%) }\end{array}$ & $\begin{array}{l}\text { The estimation of each } \\
\text { kidney capacity to } \\
\text { excrete the tracer } \\
\text { radioactive absorbed at } \\
\text { time } t=10 \text { minutes } \\
\text { after injecting }\end{array}$ & $\%$ Excretion $=\frac{C_{\max }-C_{T 10}}{C_{\max }}$ \\
\hline
\end{tabular}

Renograph IR-03 was designed compactly using present technology computer system and using radiopharmaceutical ${ }^{131}$ Ihippuran or ${ }^{99 \mathrm{~m}} \mathrm{Tc}$ DTPA [8]. This equipment has installed and used for patient examination in Sardjito General Hospital as shown in Fig. 2.

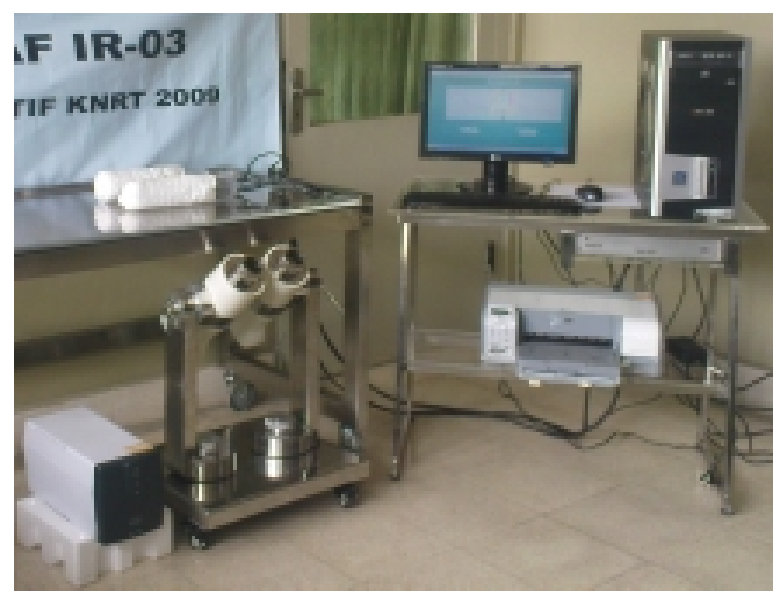

Fig. 2. Renograph IR-03 Demo Plant Instruments installed in Dr. Sardjito Hospital.

Technological analysis will be made based on the examination results obtained of system characteristic, and its correlation to the initial specifications ascertained, especially to the renogram curve analysis, operation condition of instrument during test, problems encountered and number of false of the successful of examination. Renal function analysis made from the interpretation of renogram curve of patient's kidney is more to the capacity of the de-uritic of a kidney, and not come from kidney's capacity analysis of its bio-chemical.

Base to the above perception, renal function condition can be classified into three part, they are:

1. Degradation of renal function

2. Partial obstruction

3. Normal functioning

All the renogram curves resulted from the patients are grouped into those classification, and then an inter- comparative study of patient's kidney diagnosis using renograph and laboratory-test methods is conducted. In laboratory-test methods, the part of creatinine and ureum elements in blood is tested, normal values for creatinine is 0.6 up to $1.1 \mathrm{mg} \%$, and for ureum is 10 up to $50 \mathrm{mg} \%$, respectivelly.

\section{Economy analysis of invest for renograph}

Economic cost analysis was calculated based on the cost component required for operation of renograph as the whole, i.e. Direct Cost (DC) and 
Indirect Cost(IC), or usually called Overhead Cost. DC consist of Fixed Cost (FC) that is cost for instruments procurement, maintenance cost and cost for personnels, and Variable Cost (VC) formed by all kins of supplies. Indirect Cost or Overhead Cost in the field of service industries such as health service can reach up to $50 \%$ of Direct Cost [9]. The administration cost (such as personnels, supervisor, fee for rooms, maintenance room/building, utilities, security, cost for parking, and officials ), education services, transcription, insurance, and billing cost, are included to the above mentioned cost. All of those costs is predicted for one year calculation.

Total cost per year to perform $\mathrm{X}$ times renogram examination procedure is the sum of $\mathrm{FC}$ and VC, or it can be written :

$$
\mathrm{TC}_{(\mathrm{X})}=\mathrm{FC}+\mathrm{VC}_{(\mathrm{X})}=\mathrm{FC}+\mathrm{cX}
$$

where $\mathrm{c}$ is the variable cost for one time examination procedure.

Total Revenue (TR) obtained for $\mathrm{X}$ times of procedure with the sold price of one time procedure equal to $\mathrm{p}$ is $\mathrm{TR}_{(\mathrm{X})}=\mathrm{pX}$, with the cost $=\mathrm{cX}$.

\section{Break Event Point (BEP) Analysis}

In the BEP condition, $\mathrm{TR}=\mathrm{TC}$, or $\mathrm{pX}=\mathrm{FC}+$ $c X$. Or $F C=X(p-c)$. By this condition, the number of procedure required to reach the Break Event Point is :

$$
B E P=X=\frac{F C}{p-c}
$$

\section{Rate of Return (ROR) Analysis}

Net Present Value (NPV) or Rate of Return ( ROR) draws the rate of interest $i^{*}$ that valid for a series of cash flow in balance condition (revenue equal to expense). This rate of interest then compared to the Minimum Attractive Rate of Return (MARR), that is analogous to the loan rate of interest offer by the Bank in that time. In this case $\mathrm{NPV}=0[10,11]$, or :

$$
N P V=\sum_{t=0}^{N} F_{t}\left(1+i^{*}\right)^{-t}=0
$$

where $\mathrm{F}_{\mathrm{t}}=$ cash flow at period $\mathrm{t}$ (maybe positive value/revenue, and negative value/expense) $\mathrm{N}=$ project duration, $\mathrm{i}^{*}=$ discount rate or $\mathrm{ROR}$ value of capital investment.

NPV can be written in completely as NPV $=$ $P V_{R}-P_{E}$ (Present Value Revenue - Present Value Expense), then the equation (3) can be written as :

$$
\sum_{t=0}^{N} R_{t}\left(P / F, i^{*} \%, t\right)-\sum_{t=0}^{N} E_{t}\left(P / F, i^{*} \%, t\right)=0
$$

where $R_{t}=$ Nett revenue at the period $t, E_{t}=$ Nett expense at period $t$, including the original investment $\mathrm{P}_{\mathrm{o}}, \mathrm{F} / \mathrm{P}=\left(1+\mathrm{i}^{*}\right)^{\mathrm{N}}$ or Present Worth $\mathrm{P} / \mathrm{F}=\left(1+\mathrm{i}^{*}\right)^{-\mathrm{N}}$

The value of $i^{*}$ can be observed by using Linear Interpolation methods and looking at Table of Complex Rate of Interest. For $t=10$, the Present Value $\left(\mathrm{P} / \mathrm{F}, \mathrm{i}^{*}, 10\right) \mathrm{i}$ :

$\mathrm{NPV}_{10}=\mathrm{PV}_{\mathrm{R} 10}-\mathrm{PV}_{\mathrm{E} 10}=\mathrm{R}_{10}\left(\mathrm{P} / \mathrm{F}, \mathrm{i}^{*} \%, 10\right)-\mathrm{P}_{\mathrm{o}}=0$

or Present Value factor PV(P/F, i $\left.{ }^{*} \%, 10\right)=\mathrm{Po} / \mathrm{Ro}$. By looking at Table of Complex Rate of Interest and using Linear Interpolation Methods, the value of $i^{*}$ can be obtained. This $i^{*} \%$ rate of interest then compared to the MARR, if $i^{*}$ observed $\geq$ MARR the investment to the project is not reliable, but if $i^{*}>$ MARR, then the investment for the project is reliable.

\section{Payback Period (PP), the time velocity for returning back Capital}

The time velocity in returning back the capital spent for the project can be calculated by using the following formula:

$$
P=\sum_{t=1}^{t=N_{p}} N C F_{t}(P / F, i, t)
$$

or if time value of money is neglected, the formula (6) become :

$$
P=\sum_{t=1}^{t=N_{p}} N C F_{t}
$$

If the series of cash flow is same for any time, then $\mathrm{N}_{\mathrm{P}}$ can be calculated, that is :

$$
N_{p}=\frac{P}{N C F}, \text { or } N_{P}=\frac{P}{N C F+\text { Depreciation }}
$$

where $\mathrm{P}=$ original invest capital of money, $\mathrm{NCF}=$ Net Cash Flow

To perform the Techno-Economy Study of renograph IR-03 business in hospital, it is needed to calculate the BEP, ROR and PP, by using a necessary data which is compiled in Attachment 1. The technical instrument life time is compiled to the BEDP of renograph IR-03 that is 10 years maximum. 
The economic use life time is taken generally about 40 to $60 \%$ of technical life time, or could also determined based on the Time Value of Money Concept, using the formula :

$$
N P V=\sum_{i=1}^{N} \frac{F_{t}}{\left(1+i^{*}\right)^{N}}-F_{o}
$$

At condition where the instrument has not anymore the economic value $(\mathrm{N}=\mathrm{t})$, the $\mathrm{NPV}=0$,

or $N P V=\frac{F_{t}}{(1+0,226)^{t}}-F_{o}=0$ or $\frac{50 \text { million }}{(1,226)^{t}}-250$ million $=0$

or $(1,226)^{\mathrm{t}}=250 / 50=5$, so $\mathrm{t} \sim 8$ years. The economic life time is estimated of $60 \%$ x 8 years, that is 5 years.

The number of treatment/procedure or examination required to reach the $\mathrm{BEP}$ condition is :

$$
B E P=X=\frac{\text { Fixed } \text {.Cost }}{p-c}=\frac{107,500,000}{175,000-85,000}=1,194 \text { treatments } / \text { procedures }
$$

This mean that the procentage to the total target treatment/year is $1,194 / 2,000 \times 100 \%=59.7 \%$, and this is equal to the total of money : 1,194 x IDR. 175,000.- = IDR. 209,475,000.-

To have a look more on the economic feasibility analysis, a cash flow methods of Rate of Return analysis is carried out, that is to calculate how rise the rate of interest $\left(i^{*}\right)$ get from the investment of capital to renograph, and these interest then compared with MARR. In this case, the calculation of ROR is based on the estimation that NCF is same for along time and neglects the time value of money, thus the value is : $\mathrm{NCF}=(2,000 \quad \mathrm{x}$ IDR. $1,750,000-$ IDR. 212,500,000) = IDR.137,500,000.

Then, the Payback Period can be calculated using formula 8 :

$N_{P}=\frac{P}{N C F+\text { Depreciation }}=\frac{250,000,000 .-}{137,500,000+20,000}$ year $=1,8179$ year

From estimation made that the economic age of renograph $t=5$ years, then the $\mathrm{NPV}_{5}$ can be calculated as the following:

$$
\mathrm{NPV}_{5}=\mathrm{PV}_{\mathrm{R}}-\mathrm{PV} \mathrm{E}_{\mathrm{E}}=\mathrm{R}\left(\mathrm{F}, \mathrm{i}^{*} \%, 5\right)-\mathrm{P}=0
$$

The value of $R_{5}$ for 5 years is $R_{5}=5 \mathrm{x}$ [ IDR. 350,000,000 - IDR. 212,500,000)

$\mathrm{R}_{5}=$ IDR. 687,500,000, then equation (7) can be written :

$\mathrm{NVP}_{5}=687,500,000\left(\mathrm{P} / \mathrm{F}, \mathrm{i}^{*} \%, 5\right)-250,000,000=0$ so, the present value factor $\left(\mathrm{P} / \mathrm{F}, \mathrm{i}^{*}, 5\right) 250,000,000$.$/ 687,500,000=0,3634$ by looking to the Table of Compound Interest Factor or Discret Compound Table, the quantity of the above present value lie between the interest $20 \%$ and $25 \%$, that is the present value factor $(\mathrm{P} / \mathrm{F}, 25 \%$, $5)=0,32768$ and $(\mathrm{P} / \mathrm{F}, 20 \%, 5)=0,4188$. This situation was drawn in Fig. 3. By the Linear Interpolation Techniques, the value of $\mathrm{i}^{*}$ can be calculated.

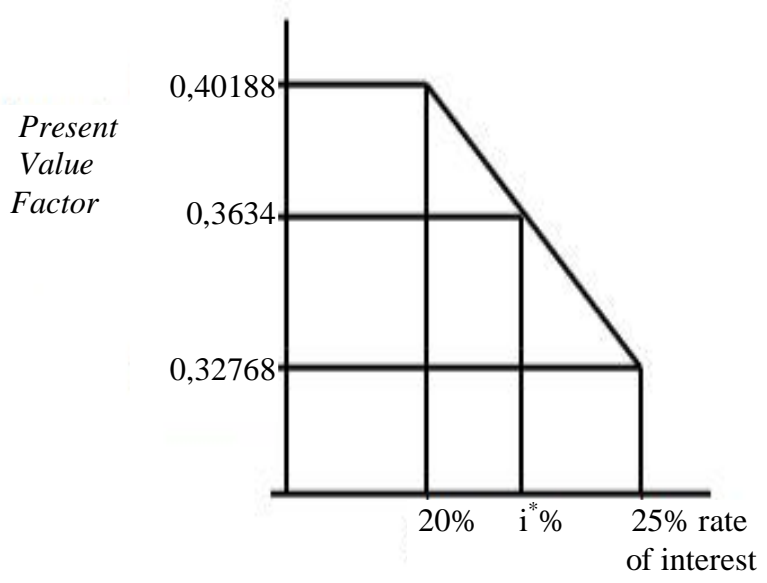

Fig. 3. Interpolation Linear methods, the calculation for $i^{*}$.

From Fig. 3, the interest rate $i^{*}$ the can be calculated as the following:

$$
\frac{25-i^{*}}{25-20}=\frac{0,36340-0,32768}{0,40188-0,32768}=0,4814
$$

Then $25-\mathrm{i}^{*}=0,4814$, or $25-\mathrm{i}^{*}=5 \times 0,4814=2.4$, hence $i^{*}=(25-2.4) \%=22.6 \%$.

\section{RESULT AND DISCUSSION}

During the use of IR-03 for patient from October 19, 2009 to January 27, 2010 (14 weeks and 5 days/week), a number of 269 of patients were recorded, and 178 among them (356 number of kidneys) were selected as the samples, i.e., they were patients who had data on laboratory. In order to the necessity in medical investigation purposes, the patients were classified into gender category (male and female) and in seven grade of old from $<20$ years up to $>70$ years. Among 178 number of patients, only 165 patients who had complete data of laboratory-chek up (creatinine and ureum), while the rest 13 patients were directly measured by renograph to get their renogram curves. These two modality of examination were noted in Table 2 and 3 , and then be compared each other to have a look the inter-correlation between them. This tables show the information as the following : 
1. The male patients who have the creatinine measurement between 2 and $10 \mathrm{mg} \%$ and $>10 \mathrm{mg} \%$, and ureum measurement between 30 and $60 \mathrm{mg} \%$ and $>60 \mathrm{mg} \%$, are mostly in the range of 40 to 70 years old, that is 80 of 98 patients $(81.6 \%)$ and 59 of 98 patients $(60.2 \%)$ respectively.

2. The female patients who have the creatinine measurement between 2 and $10 \mathrm{mg} \%$ and $>10 \%$, and with the ureum measurement between 30 and $60 \mathrm{mg} \%$ and $>60 \mathrm{mg} \%$, are mostly in the range of 30 up to 60 years old, that is 50 of 70 patients $(71.4 \%)$, and 41 of 70 patients $(58.6 \%)$.

3. Light, Medium and Heavy cases of obstruction from analyzing of renogram curves does not show the significant number of patients both for male and female. For male patient, the number of bilateral total obstruction were found in 6 patients, total obstruction case at one of kidney are 10 cases ( 2 at right kidney and 8 at left kidney). Meanwhile, on the male patient, the bilateral total obstruction were found in 5 patients, total obstruction at one of kidney are 7 cases (4 at right kidney, and 3 at left kidney).

4. Renogram analysis shows that for male patient, the bilateral normal renal function were found at 3 patients, normal function kidney at right is at 3 kidneys, and at left is at 3 kidneys. Meanwhile for the female patients, the bilateral normal function were at 3 patient, normal kidney function at 4 of right kidneys, and at 5 of left kidney. Or for both male and female patients that have of two kidney (right and left) still in good condition are 6 person, they who have one of the two kidney is still good functioning are 15 persons, or the number of kidney that still in good renal function are 24 pieces. If one of the two kidneys of a person is still in good functioning, the result of their creatinine and/or ureum might be in the normal range.

Table 2. Clinical test observation of renograph IR-03 in Sardjito General Hospital (Laboratory check-up versus renogram analysis)

\begin{tabular}{|c|c|c|c|c|c|c|c|c|c|c|c|c|}
\hline \multirow{3}{*}{ Sample } & \multicolumn{3}{|c|}{ Creatinine $(\mathrm{mg} \%)$} & \multicolumn{3}{|c|}{ Ureum $(\mathrm{mg} \%)$} & \multicolumn{6}{|c|}{ Result of Renogram Urodinamic Print } \\
\hline & \multirow[t]{2}{*}{$<2$} & \multirow[t]{2}{*}{$2<x<60$} & \multirow[t]{2}{*}{$>10$} & \multirow[t]{2}{*}{$<30$} & \multirow[t]{2}{*}{$30<x<60$} & \multirow[t]{2}{*}{$>60$} & \multicolumn{2}{|c|}{$\begin{array}{c}\text { Light } \\
\text { Degradation }\end{array}$} & \multicolumn{2}{|c|}{$\begin{array}{c}\text { Medium } \\
\text { Degradation }\end{array}$} & \multicolumn{2}{|c|}{$\begin{array}{c}\text { Heavy } \\
\text { Degradation up } \\
\text { to Non- } \\
\text { Function } \\
\end{array}$} \\
\hline & & & & & & & $\mathrm{R} / \mathrm{L}$ & Bill & $\mathrm{R} / \mathrm{L}$ & Bill & $\mathrm{R} / \mathrm{L}$ & Bill \\
\hline \multicolumn{13}{|c|}{ Male } \\
\hline$<20$ year & - & - & - & - & 3 & - & - & - & - & - & - & - \\
\hline $20-30$ & - & 2 & 2 & 1 & 1 & 2 & 2 & - & - & - & 2 & 4 \\
\hline $30-40$ & 1 & 5 & 1 & 2 & & 5 & - & 2 & - & 1 & - & 3 \\
\hline $40-50$ & 2 & 32 & 7 & 3 & 8 & 19 & 7 & 4 & 2 & 1 & 8 & 12 \\
\hline $50-60$ & - & 19 & 5 & 3 & 7 & 12 & 5 & 5 & - & 1 & 4 & 6 \\
\hline $60-70$ & 1 & 11 & 5 & 4 & 4 & 9 & 1 & 2 & - & 1 & 8 & 3 \\
\hline$>70$ & 1 & 3 & - & 1 & 1 & 2 & - & 1 & 1 & - & 2 & 1 \\
\hline Sub-Total & 5 & 72 & 20 & 14 & 24 & 49 & 15 & 14 & 3 & 4 & 24 & 29 \\
\hline \multicolumn{13}{|c|}{ Female } \\
\hline$<20$ thn & 1 & 2 & - & 1 & - & 2 & 1 & - & 1 & - & 2 & - \\
\hline $20-30$ & 1 & 3 & 2 & 1 & - & 5 & 1 & - & - & - & 4 & 2 \\
\hline $30-40$ & 1 & 7 & 7 & 2 & 4 & 9 & 1 & 2 & 2 & - & 1 & 9 \\
\hline $40-50$ & 1 & 17 & 5 & 5 & 8 & 11 & 4 & 1 & 3 & 1 & 5 & 14 \\
\hline $50-60$ & 1 & 10 & 2 & 4 & 3 & 6 & 5 & - & 1 & 1 & 0 & 4 \\
\hline $60-70$ & - & 3 & - & - & - & 3 & 1 & 2 & - & - & 0 & 2 \\
\hline$>70$ & 1 & 3 & 1 & 1 & - & 4 & - & 2 & - & - & 1 & 1 \\
\hline Sub-total & 6 & 45 & 17 & 14 & 15 & 40 & 13 & 7 & 7 & 2 & 13 & 32 \\
\hline Total & 11 & 117 & 37 & 28 & 39 & 89 & 28 & 21 & 10 & 6 & 37 & 61 \\
\hline
\end{tabular}

Note $: R / L=$ Right/Left kidney, Bill $=$ Bilateral 
To have a look the correlation between the laboratory check-up results toward renogram analysis and their validation, the data in Table 2 and 3 can be arranged become Table 4 . From Table 4 it can be obtained the correlation as the following :

1. A number of 11 persons who have creatinine level is less than $2 \mathrm{mg} \%$, which also including to 28 patients who have ureum level less than $30 \mathrm{mg} \%$ or normal renal function, are close correlation shown by the renogram curve analysis, that there are 12 patients who are indicated still have good renal function (9 patients who have one of the two kidneys are still good) and 3 patients with the all two kidneys are still in good functioning. The correlation between these two modalities is good enough.

2. Majority of the patients, that is 154 persons (93.3\%) with creatinine level > $2 \mathrm{mg} \%$ and ureum level $>30 \mathrm{mg} \%$, by the renogram curve analysis indicated that the number of kidney that have degradation from light to heavy level are 255 cases $(77.3 \%)$, where 81 cases among them are on bilateral function degradation, and about 67 kidneys (20\%) are in the disfunction obstruction condition, where the 15 among them are total obstruction. So that, the renogram analysis showed there are $97.3 \%(77.3 \%+20 \%)$ kidneys observed are having problem with their function.

Table 3. Laboratory check-up versus Renogram Analysis (continue)

\begin{tabular}{|c|c|c|c|c|c|c|c|c|c|c|c|}
\hline \multirow{3}{*}{ Gender } & \multicolumn{8}{|c|}{ O b s truction } & \multirow{2}{*}{\multicolumn{3}{|c|}{ Normal }} \\
\hline & \multicolumn{2}{|c|}{ Light } & \multicolumn{2}{|c|}{ Medium } & \multicolumn{2}{|c|}{ Heavy } & \multicolumn{2}{|c|}{ Total } & & & \\
\hline & $\mathrm{R} / \mathrm{L}$ & Bill & $\mathrm{R} / \mathrm{L}$ & Bill & $\mathrm{R} / \mathrm{L}$ & Bill & $\mathrm{R} / \mathrm{L}$ & Bill & Left & Right & Bill \\
\hline \multicolumn{12}{|l|}{ Male } \\
\hline$<20$ thn & - & - & - & - & - & - & - & - & - & - & - \\
\hline $20-30$ & - & - & - & - & 1 & - & - & - & - & 1 & - \\
\hline $30-40$ & - & - & - & - & - & - & - & - & - & - & 1 \\
\hline $40-50$ & 3 & 1 & - & - & - & - & 1 & 5 & 2 & 1 & 0 \\
\hline $50-60$ & 2 & - & - & - & - & - & 6 & - & 1 & 1 & - \\
\hline $60-70$ & 1 & - & - & - & - & - & 2 & 1 & - & - & 2 \\
\hline$>70$ & - & 1 & - & - & - & - & 1 & - & - & - & 0 \\
\hline Sub-Total & 6 & 2 & 0 & 0 & 1 & 0 & 10 & 6 & 3 & 3 & 3 \\
\hline \multicolumn{12}{|l|}{ Female } \\
\hline$<20$ thn & 1 & - & - & - & - & - & 1 & - & - & - & - \\
\hline $20-30$ & - & - & - & - & 1 & - & 2 & 1 & 1 & 2 & - \\
\hline $30-40$ & - & - & - & - & - & - & 1 & 2 & 2 & 1 & 2 \\
\hline $40-50$ & 2 & 1 & - & - & - & - & 2 & 1 & 2 & - & 1 \\
\hline $50-60$ & 3 & - & - & - & 1 & - & 1 & 1 & 0 & 0 & - \\
\hline $60-70$ & 1 & - & - & - & - & - & 0 & - & - & - & - \\
\hline$>70$ & - & - & - & - & - & - & - & - & - & 1 & - \\
\hline Sub-Total & 7 & 1 & $\mathbf{0}$ & $\mathbf{0}$ & 2 & $\mathbf{0}$ & 7 & 5 & 5 & 4 & 3 \\
\hline Total & 13 & 3 & 0 & 0 & 3 & 0 & 17 & 11 & 8 & 7 & 6 \\
\hline
\end{tabular}

Table 4. The validation of Correlation Between Laboratory check-up test and Renogram analysis

\begin{tabular}{|c|c|c|c|c|c|c|c|c|c|c|c|c|c|c|}
\hline \multirow{3}{*}{ Gender } & \multicolumn{6}{|c|}{$\begin{array}{l}\text { Laboratory Check-up Results of } 165 \\
\text { patient samples (330 kidneys) }\end{array}$} & \multicolumn{8}{|c|}{ Result of Renogram Curve Analysisi } \\
\hline & \multicolumn{3}{|c|}{ Creatinine (mg\%) } & \multicolumn{3}{|c|}{$\operatorname{Ureum}(\mathrm{mg} \%)$} & \multicolumn{3}{|c|}{ Degradation of Function } & \multicolumn{4}{|c|}{ Obstruction } & \multirow[t]{2}{*}{ Normal } \\
\hline & $<2$ & $2 \sim 10$ & $>10$ & $<30$ & $30 \sim 60$ & $>60$ & Low & Med & High & Low & Med & High & Total & \\
\hline Male & 5 & 72 & 20 & 14 & 24 & 49 & $30(5)^{*}$ & $8(5)$ & $56(30)$ & $8(2)$ & 0 & 1 & $16(6)$ & $6(3)$ \\
\hline Female & 6 & 45 & 17 & 14 & 15 & 40 & $20(7)$ & $9(2)$ & $51(32)$ & $8(1)$ & 0 & 2 & $16(6)$ & $9(3)$ \\
\hline Total & 11 & 117 & 37 & 28 & 38 & 89 & $50(12)$ & $17(7)$ & $107(62)$ & $16(3)$ & 0 & 4 & $32(12)$ & $15(6)$ \\
\hline Unit & & & 165 & ersol & & & & & & $330 \mathrm{k}$ & dneys & & & \\
\hline
\end{tabular}

Note $: \mathrm{XX}(\mathrm{Y})^{*}=\mathrm{XX}$ number of case which $(\mathrm{Y})$ is number of billateral case (on the two kidneys) 



\section{Techno-economy calculation for IR-03}

From calculation made in Chapter Experimental Methods, the following result are suggested :

1. Economy life time of equipment 5 year is a rational one, less than 5 years is economically good investment. Also the rational Payback Periode is less than 5 years is a good one.

2. BEP in the amount of 1,194 procedures or values of IDR. 209,475,000. is quite good for bussiness.

3. The Rate of Interest of the renograph's investment is $22.6 \%$, is much greater than saving interest could given by the Bank, that is $10 \%$, this will give a good prospect.

In order to see more about capital invest for renograph by the estimation of sold price in several interest rate such as $20 \%, 40 \%, 60 \%, 80 \%$ and $100 \%$, the sold price, the values of BEP and PP can be obtained as shown in Table 5 .

From Table 5 , it can be concluded that the reliable economic profit was between $50 \%$ and $60 \%$ which corresponds to the value of Payback Periode less than 5 years. The PP will be decreased by the rising of the efficiency of renograph utilization, and diminishing the fixed cost as well as the variable cost.

Table 5. Calculation BEP and PP in several Profit rate

\begin{tabular}{ccccc}
\hline No. & $\begin{array}{c}\text { Profit rate } \\
(\%)\end{array}$ & $\begin{array}{c}\text { The sold } \\
\text { price (IDR) }\end{array}$ & $\begin{array}{c}\text { BEP Calculated } \\
\text { (Prosedur / \% ) }\end{array}$ & $\begin{array}{c}\text { PP } \\
\text { Calculated } \\
\text { (tahun) }\end{array}$ \\
\hline 1. & 40 & 119,000 & $3162 / 158$ & 9.80 \\
\hline 2. & 50 & 127,500 & $2559 / 128$ & 5.88 \\
\hline 3. & 60 & 136,000 & $2108 / 105$ & 4.20 \\
\hline 4. & 70 & 144,500 & $1807 / 90$ & 3.27 \\
\hline 5. & 80 & 153,000 & $1581 / 79$ & 2.67 \\
\hline 6. & 100 & 170,000 & $1265 / 63$ & 1.96 \\
\hline
\end{tabular}

The result of patient examination using renograph IR-03 were presented in Fig. 4. The patient is Mr. Subagyo, 68 years old with laboratory checked shows that creatinine $=2.18 \mathrm{mg} / \mathrm{dl}$ and ureum $=25 \mathrm{mg} / \mathrm{dl}$. His Renogram curve shows that his right kidney is still right functioning, while the left kidney is obstruction. Total obstruction case on both kidney of patient namely Mr. Tumiji is shown in Fig. 5. Although the vascular phases of the two kidneys are shown the normal function, but the parenchima phase and excretion phase showed the abnormalities, that is absorption capacity was too low and also no excretion process happened. The results of kidney parameters are also correlated to support the diagnosis made.

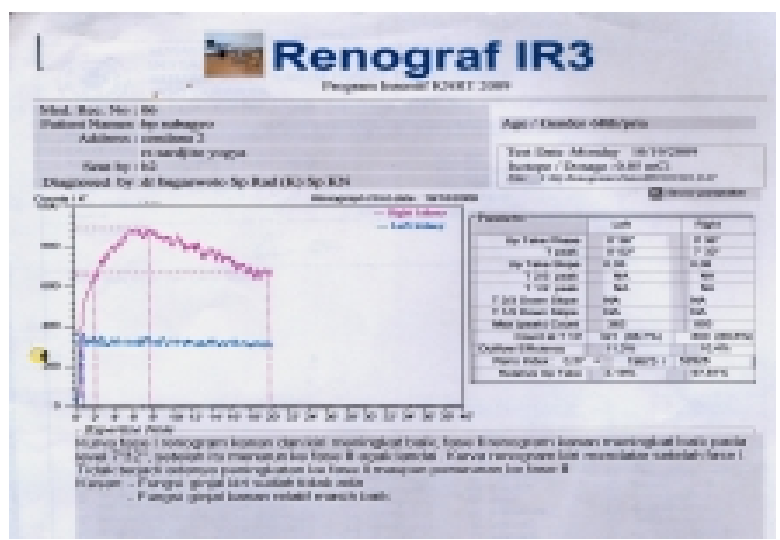

Fig. 4. Renogram curve (left kidney is not functioning) and parameters displays.

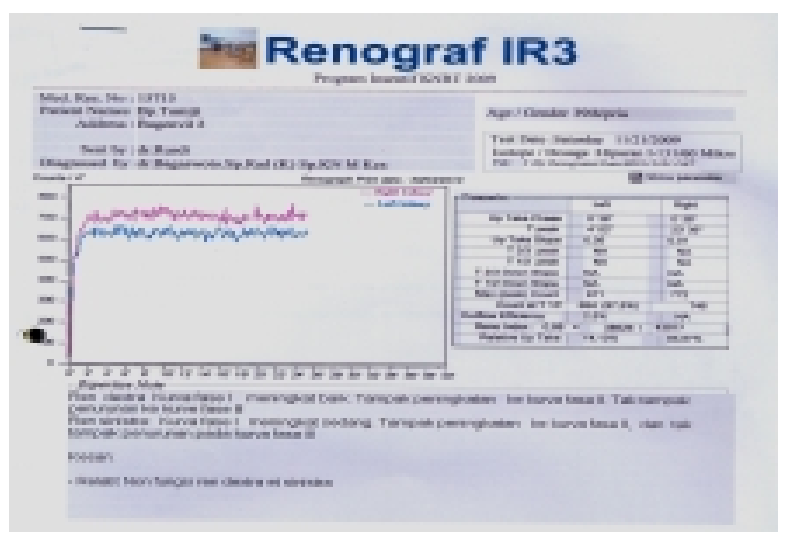

Fig. 5. Example of Renogram Curve of obstruction case at both left and right kidneys.

\section{CONCLUSION}

In summary, construction of IR-03 renograph demo plant has been finished on time and correspond to the BEDP Document, then the clinical test to the Equipment has been carried out in Dr. Sardjito General hospital, Jogyakarta with excellent result. Based on the results of the instrument performances and of the feasibility study, some conclusions were summarized as follow :

1. Application of renograph IR-03 for renal function test has been seccessfully performed and in conformity with Technical Specification established. A long fourteen weeks the clinical test run, about 269 patients have been examined ( 6 to 8 patient/day) without any trouble to the Machine.

2. Techno-economic analysis to have a look the feasibility of investment to renograph have been made by BEP, ROR and PP analyses. The results show that BEP $=59.7 \%$ or IDR. 209,475,000.--, Interest rate of investment ROR $\left(i^{*}\right)=22.6 \%$ and 
$\mathrm{PP}=1,818$ years. The results show that the investment on renograph for commercial is quite good prospect and profitable. Time needed to return back the capital is very fast (less than 2 years), Break Event Point $=59.7 \%$ is realistic, and rate of interest of investment is $22.6 \%$ much greater than the rate of interest offered by National Banks.

3. Cost analyses are important tools used by business leaders, administrators of medical services and stakeholders who made policy in the field of medical. This financial analyses is only as acurate as its underlaying assumptions, no model can describe reality perfectly, but the estimations made were considered the important factors in using renograph.

\section{SUGGESTION}

In order that the result of this research in engineering design of renograph IR-03 could be applied under a legal-aspect in hospitals and policlinics, the last step must be done, that is to obtain the certification of product of renograph IR-03 protoype from the office of Ministry of Health, and its operation permit from Body for Nuclear Regulation. The more of peoples who suffering of renal diseases, the more of equipments needed for examination, this is the chance!.

\section{ACKNOWLEDGEMENTS}

This work was financial supported by Research Incentive Program, Ministry of Reserach and Technology Indonesia under contract No. 025/KP/D.PSIPTN/Insentif/PPK/2009. We would like to express our thanks to the Office of Ministry Research and Technology for their support and funds. This work is supported by scientists, engineers and technicians of PRPN-BATAN, Serpong and PTAPB-BATAN, Jogyakarta. The authors would like to express our appreciate and thanks to Mr.Wiranto B.S. et.al., and Mrs. Dewita et.al. for their contribution.

\section{REFERENCES}

1. http://www.google.com/renal/renal diseases/da ta of patient/. Retrieved in March (2012).

2. Eva V. Dubovsky, Quantitation of Renal Function, Proceedings of the $5^{\text {th }}$ Asia and Oceania Congress of Nuclear Medicine and Biology I (1992) 331.

3. R. Isaris and W.S. Setyadi, Evolution Design and Construction of Renograph for Renal Function Test, Proceedings of the $4^{\text {th }}$ Kentingan Physics Forum, A Biannual Conference on Physics and Its Application (2007) 293.

4. B.R. Bairi, B. Singh, N.C. Rathod and P.V. Narurkar, Handbook of Nuclear Medicine Instruments, Tata McGraw Hill, New Delhi (1994) 49.

5. G. Suyitno and R. Ishandono, ${ }^{131}$ I Hippuran Renography in Clinical Application for Renal Function Test, A Comparative Study to Renal Ultra Sonography, Proceedings of Annual Congress on Nuclear Medicine and Biology Society (1989) 197.

6. P.H. O'Reilly, R.A. Shield and H.J. Testa, Nuclear Medicine in Urology and Nephrology, $2^{\text {nd }}$ ed. Book, Butterworths, London and Boston (1979).

7. G. Suyitno, Medical Presented Data of Refurbishing Aged Renogram System,Technical Report of RAS/04/017 IAEA Programme, The IAEA Regional Training Workshop,Yangon, Myanmar (2001).

8. J. Sumanto, Majalah Ilmiah PRIMA, 5 (10) (2008).

9. R.G. Evens, Cost Accounting in Radiologi and Nuclear Medicine, CRC Crit.Rev Clinical Radiology Nuclear Medicine 6 (1975) 67.

10. N. Pujawan, I. Ekonomi Teknik, Pemilihan Alternatif-Alternatif Ekonomi, Guna Widya (1995) 88.

11. F. Raharjo, Ekonomi Teknik, Analisis Pengambilan Keputusan, Analisis NPV, PP dan ROR, Andi, Jogyakarta (2007) 8. 
Attachment 1. Yearly cost required on the Utilization of one Unit Renograph IR-03

\begin{tabular}{|c|c|c|c|}
\hline No. & Cost component & Value & Identification \\
\hline \multirow[t]{9}{*}{1.} & Data and estimation for Technical- & & Reffered to the BEDP \\
\hline & Economy calculation & & Documents of renograph PRPN- \\
\hline & a. Techniques life time & 10 years & $\begin{array}{l}2008 \text {, based to the component } \\
\text { generation. }\end{array}$ \\
\hline & b. Economy Life Time & 5 years & $\begin{array}{l}\text { estimated } 40-60 \% \text { of the } \\
\text { techniques life time }\end{array}$ \\
\hline & $\begin{array}{l}\text { c. Purchasing one batch of }{ }^{131} \mathrm{I} \\
\text { hippuran ( } 1 \text { batch }=7 \mathrm{mCi} / \text { week })\end{array}$ & IDR.1,250,000 & Supplier PT. BATAN Tek \\
\hline & $\begin{array}{l}\text { d. Radioisotop price/procedure } \\
(=50 \mu \mathrm{Ci} / \text { procedure })\end{array}$ & IDR. 8,928 & Estimation \\
\hline & $\begin{array}{l}\text { e. Prediction number of patient per } \\
\text { week }=40 \text { persons or } 2,000 \mathrm{ps} / \mathrm{yr}\end{array}$ & 2,000 patients/year & one year $\sim 50$ weeks \\
\hline & $\begin{array}{l}\text { f. Variable cost } 1 \text { time procedure/ } \\
\text { examination : } \\
\mathrm{c}=\text { Total Cost/number of procedure } \\
\mathrm{c}=\text { IDR.161,600,000/2,000 }\end{array}$ & IDR. 85,000 & Cost per prosedure \\
\hline & g. Tarif for each procedure $(\mathrm{p})$ & IDR. 175,000 & $\begin{array}{lrr}\text { Normal tariff } \\
\text { examination/test }\end{array}$ for renal \\
\hline \multirow[t]{13}{*}{2.} & DIRECT COST & & \\
\hline & Fixed Cost & & \\
\hline & a. Fixed Capital $(\mathrm{P})$ & $\begin{array}{l}\text { IDR. 250,000,000 } \\
\text { (IDR. 50,000,000/yr) }\end{array}$ & $\begin{array}{l}\text { (Development Cost }+ \\
\text { Construction cost) }\end{array}$ \\
\hline & b. Nilai akhir Alat $(\mathrm{S})$ & IDR. $50,000,000$ & Estimation value \\
\hline & c. Maintenance cost $(10 \%)$ & IDR. $25,000,000$ & Normative rate \\
\hline & d. Depreciation & IDR. 20,000,000 & $\begin{array}{l}\text { Calculated based to Stright Line } \\
\text { Methods: } \\
\quad \text { IDR. }(250-50) \mathrm{M}\end{array}$ \\
\hline & e. Insurance (5\%) & IDR. $12,500,000$ & $\mathrm{D}_{10}=$ \\
\hline & Sub-Total & IDR. 107,500,000 & 10 \\
\hline & Variable Cost & & $=\mathrm{IDR} 20 \mathrm{M}$ \\
\hline & a. e. Salaries (1D, 1MP, 1E, 1AN) & IDR. 60,000,000 & Normative rate \\
\hline & f. Supplies /year & IDR. $15,000,000$ & \\
\hline & g. Radiopharmaceutical 24 batch/yr & IDR. $30,000,000$ & $\begin{array}{l}\text { (Additional salaries) } \\
\text { Replaceparts, supplies }\end{array}$ \\
\hline & Sub-Total & IDR. 105,000,000 & FOB on hospital \\
\hline & Sub Total/year & IDR. 212,500,000 & \\
\hline \multirow[t]{3}{*}{3.} & INDIRECT COST & & \\
\hline & 1. Overhead Cost ,20\% Direct Cost & IDR. $34,000,000$ & R.G. Evens [9], 20 up to $50 \%$, \\
\hline & Total/year & IDR. 246,500,000 & \\
\hline
\end{tabular}

